\title{
Incidência de normas concorrenciais em cooperativas: a intervenção estatal sobre Cooperativas no Brasil
}

\author{
Incidence of Competition Rules in Cooperatives: \\ State intervention on Cooperatives in Brazil
}

\author{
Giselle Borges Alves \\ Mestra em Direito pela Universidade de Brasília (UnB), \\ professora de graduação em Direito e Advogada
}

Sumário: I. Introdução. II. A Sociedade Cooperativa: intercooperação, propriedade e gestão. III. O cooperativismo brasileiro em perspectiva constitucional. IV. A incidência de normas concorrenciais sobre cooperativas. 4.1. Controle de condutas. 4.1.1. Cartel. 4.1.2. Acordos de exclusividade. 4.1.3. Imposição de tabela de honorários. 4.1.4. Recusas de contratar. V. A medida de intervenção estatal. VI. Conclusões. Bibliografia.

Resumo: As atividades econômicas desenvolvidas pelas cooperativas brasileiras durante décadas têm despertado a atuação do Conselho Administrativo de Defesa Econômica (CADE), tendo em vista que a garantia constitucional de não intervenção estatal (art. 5. ${ }^{\circ}$, XVIII) não pressupõe imunidade à aplicação da legislação antitruste. Diante deste enfoque, a pesquisa teve como objetivo analisar algumas das decisões do CADE sobre as sociedades cooperativas, bem como estabelecer a necessidade de reflexão sobre as características e peculiaridades distintivas das sociedades cooperativas que justificam a coordenação de agentes no mercado.

Palavras-chave: cooperativismo, antitruste, intervenção estatal.

Abstract: The economic activities developed by Brazilian cooperatives for decades have awakened the work of the Administrative Council for Economic Defense (CADE), considering that the constitutional guarantee of non-state intervention (art. 5, XVIII) does not presuppose immunity to the application of antitrust legislation. Given this focus, the research aimed to analyze some of CADE's decisions on cooperative societies, as well as establishing the need for reflection on the characteristics and peculiarities distinctive of cooperative societies that justify the coordination of agents in the market.

Keywords: cooperativism, antitrust, state intervention. 


\section{Introdução}

O histórico do movimento cooperativista apresenta raízes no socialismo utópico, notadamente quanto aos ideais de justiça e fraternidade por meio de organizações sociais equitativas voltadas à melhoria socioeconômica. No entanto, apesar de ter raízes no socialismo, o cooperativismo não se desenvolveu integralmente atrelado a este, incorporando também a filosofia capitalista, na medida em que seus associados unem forças para competir em condições de igualdade com outros agentes econômicos. Há, portanto, um respeito às diretrizes do capitalismo, propiciando agregação de renda e também certa aproximação com a doutrina socialista em razão do prisma do coletivismo em termos de propriedade e partilha do resultado comum obtido entre os associados ${ }^{1}$.

O modelo de gestão das cooperativas, baseado em laços de solidariedade que fazem da estrutura do empreendimento cooperativo mais competitivo e foram primordiais para ao seu crescimento, também trouxeram alguns desafios às autoridades concorrenciais, notadamente quanto à correta compreensão da propriedade cooperativa e da própria dimensão do princípio da intercooperação entre cooperativas. Assim, a própria arquitetura do empreendimento causa estranheza e dúvida, o que, muitas vezes, pode levar a preconcepções superficiais sobre a atuação da cooperativa dentro de determinados mercados.

As cooperativas têm o desafio de serem competitivas no mercado e solidárias com os cooperados e cumprirem, ainda, o princípio de cooperarem entre si (intercooperação entre cooperativas). Devem juntas servir ao movimento. Entretanto, há quase sempre uma presunção de culpabilidade em desfavor das cooperativas, em razão da reunião de potenciais competidores em um único empreendimento.

Logo, o presente estudo se justifica diante da necessidade de analisar as características da atuação da cooperativa no mercado, dadas as peculiaridades inerentes a natureza jurídica, seus objetivos e a própria arquitetura do empreendimento, bem como verificar se essas peculiaridades revelam uma necessidade de atuação diferenciada das autoridades de defesa da concorrência, quando identificado abuso do direito de associação e desvirtuamento da finalidade não-lucrativa da sociedade cooperativa diante de comprovada concentração de poder econômico.

1 MEINEN, Ênio. As sociedades cooperativas na Constituição Federal. In: Aspectos jurídicos do cooperativismo. Série Cooperativas I. Jane Aparecida Stefanes Domingues (org.). Porto Alegre: Editora Sagra Luzzatto, 2002, p. 13. 
Neste sentido, a abordagem realizada no presente estudo perpassa quatro momentos. O primeiro analisa as peculiaridades relativas a propriedade, gestão e integração cooperativista. Em um segundo momento, temos o paralelo sobre o cooperativismo brasileiro e sua regulação jurídico-constitucional. No terceiro momento, foi realizada uma análise da atuação do CADE - Conselho Administrativo de Defesa Econômica, sobre as cooperativas brasileiras. Por fim, o leitor é levado a uma reflexão sobre a atuação da autoridade concorrencial brasileira sobre cooperativas.

\section{A sociedade cooperativa: intercooperação, propriedade e gestão}

Tradicionalmente as cooperativas nasceram sob a ótica de pequenos empreendimentos solidários, voltados a possibilitar a inserção de pequenos e médios trabalhadores na economia capitalista com competitividade e, em razão disso, o cooperativismo, em suas raízes, foi identificado por alguns de seus instituidores como uma oposição ao próprio conceito de concorrência ${ }^{2}$. No entanto, ao longo dos anos os empreendimentos cooperativos deixaram de ser caracterizados apenas dentro do loco da economia solidária, uma vez que a própria estruturação possibilitada pela lei geral das cooperativas brasileiras - Lei n. ${ }^{\circ}$ 5.764/1971-, tanto sob o prisma das integrações verticais e horizontais entre cooperativas, como a possibilidade de inter-relacionamento com outras empresas mercantis, foi responsável por possibilitar que as cooperativas se tornassem grandes empreendimentos, similares, em muitos aspectos, às sociedades empresárias ${ }^{3}$.

Inicialmente, as cooperativas colaboravam entre si apenas sob a ótica do princípio da intercooperação, com concentrações de atividades promovidas através de arranjos para redução de intermediários, operações com maior ganho de escala, estabilização de atividades e redução de custos. Entretanto, com o advento da Lei Geral de Cooperativas, em 1971, criaram-se condições legais para a integração entre cooperativas e demais firmas não-cooperativas, o que, na visão de Paul Singer, se re-

2 PINHO, Diva Benevides. Economia e cooperativismo. São Paulo: Saraiva, 1977, p. 72-75; e BIALOSKORSKI NETO, Sigismundo. Economia e gestão de organizações cooperativas. 2. ed. São Paulo: Atlas, 2012, pp. 7-15.

3 Diva Benevides Pinho, já na década de 1970, alertava sobre o gigantismo do modelo cooperativista (PINHO, Diva Benevides. Economia e cooperativismo. São Paulo: Saraiva, 1977, p. 13). 
velou como parte integrante da própria formação social capitalista, em que a concentração de capital é necessária ao progresso técnico, sendo também determinante para a competitividade no mercado ${ }^{4}$. Inclusive, a formação de conglomerados ou complexos cooperativistas, com a junção de cooperativas de diversos ramos de atividades que são complementares, é tendência na economia capitalista, substituindo a mão invisível do mercado pela mão da coordenação e do planejamento dentro da econômica solidária, em que a competição não é a regra, mas sim os laços de solidariedade e colaboração com vistas a ganhos de produtividade e para atender às demandas do mercado 5 .

Portanto, é imperativo no contexto da doutrina econômica cooperativista que a concentração de cooperativas ou destas com empresas não-cooperativas não caracterize desvio da filosofia do movimento, desde que a conjugação de atividades seja para a melhoria dos serviços prestados ao próprio associado e implique em aumento de bem-estar para o mercado.

Em relação a arquitetura da cooperativa, esta envolve a comunhão de escopo, tanto na fase de determinação do objeto social, como na confluência de vontade dos cooperados na realização das atividades. Poder de controle e propriedade se entrelaçam profundamente, o que faz o próprio design da propriedade cooperativa ser diferente em estrutura e substância, na tentativa de realizar um capitalismo inclusivo. As cooperativas são caracterizadas, principalmente, sob a ótica de atos internos, voltados aos cooperados: os atos cooperativos. Assim, as cooperativas são desenvolvidas para possibilitar a eficiência econômica de seus membros, diminuindo a atuação de intermediários dentro de uma cadeia produtiva ou de prestação de serviços.

Dentro do prisma de que todas as atividades por ela desempenhadas são para favorecer seus donos-usuários, a cooperativa pode ser concebida, conforme visão de Lamming, como «parte integral ou extensão das empresas individuais de seus associados» ${ }^{6}$. Em uma so-

4 SINGER, Paul. Economia solidária versus economia capitalista. Revista Sociedade e Estado. Instituto de Ciências Sociais da Universidade de Brasília. vol. 16. n. 1-2. Brasília: jun./dez., 2001, p. 109.

5 SINGER, Paul. Economia solidária versus economia capitalista. Revista Sociedade e Estado. Instituto de Ciências Sociais da Universidade de Brasília. vol. 16. n. 1-2. Brasília: jun./dez., 2001, p. 110.

6 LAMMING, Goodwin Norman. Eficiência em administração de cooperativas. In: A problemática do cooperativismo no desenvolvimento econômico. São Paulo: Fundação Friedrich Naumann, 1973, p. 283. Destaque-se, ainda, que sob o ponto de vista econômico, as cooperativas não possuem existência independente de seus membros, como acontece nas sociedades de capital, sendo na visão de Bialoskorski Neto, uma «organi- 
ciedade onde o associado ostenta uma dupla qualidade, sendo, ao mesmo tempo, dono e cliente dos serviços ofertados, os atos da cooperativa são, essencialmente, mecanismos que possibilitam que o fator trabalho se sobreponha ao capital. Portanto, o direito a uso dos serviços se contrapõe ao direito aos lucros comuns das sociedades capitalistas convencionais.

Por conseguinte, a ótica de Lamming expressa também as conclusões de Hart e Moore, ou seja, de que o associado da cooperativa é cousuário, co-participante e co-fiscal no empreendimento ${ }^{7}$. Neste viés, a própria gestão do empreendimento cooperativo ganha singularidade, tendo em vista que possui como foco os direitos de decisão e controle direto, ou seja, uma propriedade baseada nos mecanismos de autogestão, ação compromissada e não-oportunista ${ }^{8}$. 0 design da propriedade cooperativa se destaca, deste modo, como uma alternativa para a realização de um capitalismo inclusivo, pois define um modelo de economia auto-organizada e autogerida pelos donos-usuários do empreendimento, com uma função social preponderante, gerando riqueza aliada ao desenvolvimento social e sustentável.

Em vista disso, a remuneração sobre o capital é praticamente inexistente ou inexpressiva, recaindo a remuneração sobre o trabalho realizado pelo cooperado junto à cooperativa. No momento em que o associado manifesta o desejo de deixar a sociedade, não possuirá qual-

zação econômica intermediária», pois é colocada a serviço dos interesses dos associados, para maximização de benefícios a estes («máximo de eficiência física»), o que não pressupõe o «máximo de eficiência econômica», justamente em razão da ausência de finalidade lucrativa (BIALOSKORSKI NETO, Sigismundo. Economia e gestão de organizações cooperativas. 2. ed. São Paulo: Atlas, 2012, pp. 18-26).

7 LAMMING, Goodwin Norman. Eficiência em administração de cooperativas. In: $A$ problemática do cooperativismo no desenvolvimento econômico. São Paulo: Fundação Friedrich Naumann, 1973, p. 293; e HART, Oliver; MOORE, John. Cooperatives vs outside ownership. Havard University, 1998, pp. 4-5.

8 BIALOSKORSKI NETO, Sigismundo. Economia e gestão de organizações cooperativas. 2. ed. São Paulo: Atlas, 2012, p. 48. Neste sentido, Lamming e Bialoskorski Neto afirmam que a unidade existente entre os associados da cooperativa não ocorre apenas sob o prisma da propriedade e do controle, mas também, entre o uso e o controle (LAMMING, Goodwin Norman. Eficiência em administração de cooperativas. In: A problemática do cooperativismo no desenvolvimento econômico. São Paulo: Fundação Friedrich Naumann, 1973, p. 291; BIALOSKORSKI NETO, Sigismundo. Economia e gestão de organizações cooperativas. 2. ed. São Paulo: Atlas, 2012, pp. 99-100). No Brasil, a dimensão uso se sobrepõe a dimensão de propriedade, justamente em razão da indefinição do que seriam os direitos privados de propriedade cooperativa. O que existe são direitos «comuns» e o membro se interessa sobre a dimensão de uso dos bens comuns e dos benefícios que a cooperativa pode lhe proporcionar, logo, não há busca por rentabilidade. 
quer direito sobre os bens de produção, apenas poderá realizar o resgate do valor das suas quotas de capital. Tudo que ajudou a construir e adquirir com o fruto seu trabalho junto à cooperativa ficará em benefício dos demais associados, presentes e futuros, primando pela continuidade do movimento e a utilização máxima dos bens para o bem-estar dos associados e da comunidade.

Portanto, as cooperativas são modelos societários constituídos com a finalidade preponderante de coordenação de agentes econômicos individuais para que possam competir em condições de igualdade com os demais players do mercado.

\section{O cooperativismo brasileiro em perspectiva constitucional}

De acordo com dados divulgados pela Organização das Cooperativas Brasileiras (OCB) entre os anos de 2016 a 2019, a pujança e importância do sistema cooperativista pode ser sentida nos três ramos em que elas mais crescem no país nas últimas décadas: cerca de $48 \%$ de toda a produção agrícola brasileira passa de alguma forma por uma cooperativa agropecuária9; $31 \%$ do mercado de assistência médica suplementar é composto por cooperativas do ramo de saúde ${ }^{10} ;$ e, em 594 municípios brasileiros, as cooperativas de crédito são as únicas instituições financeiras locais ${ }^{11}$.

O desenvolvimento das cooperativas no Brasil está relacionado a expansão dos mercados, mas também possui íntima relação com a sua função social, uma vez que são constituídas com o objetivo primordial de prestar serviços aos associados. Essa função social não passou despercebida pelos Constituintes originários, que verificaram no cooperativismo um modelo de realização dos fundamentos e objetivos da República, na medida em que os valores sociais do trabalho, da livre iniciativa (art. 1. ${ }^{\circ}, \mathrm{IV}, \mathrm{CF} / 1988$ ) e os objetivos de construção de uma sociedade justa e solidária, com erradicação da pobreza e diminuição das

9 ORGANIZAÇÃO DAS COOPERATIVAS BRASILEIRAS (OCB). Relatório de Gestão OCB 2016. Somos cooperativismo. Brasília: OCB, 2016.

10 Dados divulgados pela OCB no Anuário de 2019, tendo como ano-base 2018. Ressalte-se, ainda, que de acordo com dados da ICA, referentes ao ano de 2016, a Confederação Nacional das Cooperativas Médicas Unimed do Brasil é a quarta maior cooperativa do mundo e a primeira colocada mundial no ramo de cooperativa de saúde (INTERNATIONAL CO-OPERATIVE ALIANCE (ICA). World Co-operative monitor: exploring the co-operative economy. Report 2016. ICA, pp. 8; 47).

11 ORGANIZAÇÃO DAS COOPERATIVAS BRASILEIRAS (OCB). Anuário do Cooperativismo Brasileiro. Brasília: Sistema OCB, 2019, p. 45. 
desigualdades sociais e regionais (art. 3. ${ }^{\circ}, \mathrm{CF} / 1988$ ), passa pelo incentivo a criação e livre desenvolvimento das cooperativas enquanto empreendimentos econômicos.

No regime jurídico geral do cooperativismo brasileiro, instituído na década de 1970, através da Lei n. ${ }^{\circ}$ 5.764/1971, tivemos o estabelecimento dos requisitos nucleares das cooperativas, desde suas características e positivação normativa dos princípios, até a estruturação de todo o ciclo de constituição e organização dos empreendimentos cooperativos. No entanto, por ter sido consolidada em um período de grande intervencionismo estatal sobre movimentos coletivos, a Lei Geral do Cooperativismo brasileiro, não estabeleceu os patamares de liberdade de associação e autonomia necessários a evitar a ingerência estatal. Apenas com a redemocratização, o cooperativismo passou a ser consagrado como uma espécie societária com valores democráticos inerentes, tendo sido assegurada maior liberdade na sua criação e desenvolvimento. Assim, as cooperativas ganharam status constitucional em 1988, em diversas passagens no texto da Carta Republicana brasileira ${ }^{12}$.

O próprio reconhecimento constitucional do cooperativismo traz a este modelo de desenvolvimento econômico uma estrutura mínima ${ }^{13}$, uma vez que a Constituição Federal de 1988 elenca a necessidade de incentivo a criação e desenvolvimento desta espécie societária (art.174, $\left.\S 2 .^{\circ}\right)$ e afirma a necessidade de mínima intervenção estatal no desenvolvimento das atividades cooperativas (art. 5. ${ }^{\circ}$, inciso XVIII). Neste prisma, o constituinte originário estabeleceu que a regulação desta espécie societária deve observar o seu pleno desenvolvimento de modo a possibilitar o crescimento e expansão das atividades econômicas desenvolvidas pelas cooperativas.

12 Entre as disposições relacionadas ao cooperativismo na Constituição Federal de 1988, podemos citar: o art. $5^{\circ}, \mathrm{XVIII}$, que estabeleceu como garantia fundamental a autonomia das cooperativas, vedando comandos infraconstitucionais que interfiram em suas atividades ou que exijam autorização para o seu funcionamento; nas questões relativas ao sistema tributário nacional, o art. 146, III, alínea "C», trata da necessidade de legislação complementar para o estabelecimento de um adequado tratamento tributário ao ato cooperativo; sob o enfoque dos princípios gerais que devem nortear a atividade econômica no país, o art. 174, caput e $\S \S 2 .^{\circ}, 3 .^{\circ}$ e $4 .^{\circ}$, afirmam a necessidade de um olhar diferenciado sobre as atividades realizadas por cooperativas, apoiando e estimulando o trabalho de cunho associativo; tem-se, ainda, o aporte ao fomento do cooperativismo dentro da política agrícola nacional (Art. 187, VI) e no sistema financeiro nacional, com menção expressa as cooperativas de crédito (Art. 192).

13 MEINEN, Ênio. As sociedades cooperativas na Constituição Federal. In: DOMINGUES, Jane Aparecida Stefanes (org.). Aspectos jurídicos do cooperativismo. Série Cooperativas I. Porto Alegre: Editora Sagra Luzzatto, 2002, pp. 14-18. 
A Constituição Federal de 1988 destaca, desta forma, a importância socioeconômica do cooperativismo, direcionando normativamente as atividades estatais para estabelecer uma ordem econômica voltada para a redução das desigualdades regionais e sociais e a busca do pleno emprego (incisos VII e VIII, art. 170, CF/88), com o estímulo a formas de exercício de atividades econômicas que possibilitem a realização destes pilares de desenvolvimento social, dentro de um modelo constitucional-econômico de bem-estar ${ }^{14}$.

Entretanto, apesar das cooperativas possuírem uma construção sobre pilares axiológicos que em grande medida realçam aspectos morais e éticos do movimento, o que se percebeu nas últimas décadas é que as cooperativas podem praticar atos comuns de mercado ${ }^{15}$ e se envolverem em ilícitos, inclusive de natureza concorrencial, fazendo surgir a necessidade de adequação de suas práticas e o tratamento dispensado a elas, muitas vezes, não é diverso de outras pessoas jurídicas. Neste sentido, na análise dos contornos estabelecidos pela Constituição Federal de 1988 quanto à garantia de não-intervenção estatal nas cooperativas, estabelecido pelo artigo $5 .^{\circ}$, inciso XVIII, tornou-se pacífico o entendimento de que a bússola orientadora do intérprete deve ser composta pelos parâmetros de legalidade impostos pelo ordenamento jurídico e com atenção aos interesses da coletividade.

\section{A incidência de normas concorrenciais sobre cooperativas}

O Cooperativismo, conforme visto, permite a união de pessoas físicas e jurídicas, bem como de categorias profissionais de determinado segmento econômico em um empreendimento comum, o que pode, muitas vezes, ser interpretado como um ilícito de natureza concorrencial, culminando com a atuação dos órgãos estatais de controle. No entanto, a aplicação da legislação antitruste sobre cooperativas é, por vezes, questionada em razão da não compreensão exata das peculiaridades e da filosofia deste movimento ${ }^{16}$. Ressalte-se que não se trata de

14 Neste sentido, ver a exposição de GRAU, Eros Roberto. A ordem econômica na constituição de 1988: interpretação e crítica. 17. ed. rev. atual. São Paulo: Malheiros Editores, 2015, pp. 45-47.

15 No entanto, existem controvérsias dentro da doutrina cooperativista quanto à possibilidade de se considerar que as cooperativas realizam atos de mercado. Neste sentido ver NASCIMENTO, Carlos Valder do. Teoria geral dos atos cooperativos. São Paulo: Malheiros, 2007, pp.89-92.

16 Neste sentido, Krueger reivindica uma correta compreensão do que são os atos de cooperação, para "além dos estreitos limites pragmáticos do cálculo utilitário» 
uma pauta simplória de não-intervenção da autoridade antitruste, cuja controvérsia foi pacificada, a discussão atual está notadamente submetida à correta identificação de quando a atuação de uma cooperativa traz prejuízo ao mercado, bem como à metodologia de aplicação de sanções, à proporcionalidade destas e ao enforcement desejado pela autoridade antitruste, principalmente sobre os casos reiterados de condutas anticompetitivas.

Os casos que envolvem atos praticados por cooperativas que ensejaram atuação direta do CADE, remontam à década de 1980, com forte sancionamento sobre cooperativas de saúde e de trabalho médico. O mercado de saúde suplementar foi o que demandou maior atenção da autoridade antitruste brasileira, entretanto, também se evidencia da jurisprudência do CADE a atuação de cooperativas do ramo agropecuário na formação de cartéis, com a prática de atos colusivos em conjunto com outras cooperativas e sociedades empresárias, não sendo raras as vezes em que as cooperativas são acusadas de agirem como empresas capitalistas convencionais, buscando a dominação de mercado e aumento arbitrário dos lucros.

No Brasil, atualmente a Lei n. ${ }^{\circ} 12.529 / 2011$ realiza a estruturação do sistema de defesa da concorrência e dispõe sobre mecanismos de prevenção e repressão às infrações à ordem econômica, coibindo práticas que prejudicam a liberdade de negociação no mercado. A norma não realiza distinção entre cooperativas e demais pessoas jurídicas, para fins de defesa da concorrência e aplicação de sanções para os ilícitos praticados, colocando as cooperativas entre as pessoas jurídicas em geral (art. 31) e, via de regra, as sanções por ilícitos concorrenciais são aplicadas com fulcro no art. 37, II, não atribuindo as cooperativas a noção de empresariedade. Assim, a atual lei de defesa da concorrência não faz menção expressa as sociedades cooperativas enquanto pessoa jurídica sui generis, não conferindo a elas qualquer tratamento diferenciado ou imunidade, ao contrário do que ocorre, por exemplo, na legislação norte-americana que concede uma isenção legal (legal exemptions) às cooperativas agrícolas conforme as chamadas «isenções em bloco» que são concedidas a determinados setores em prol do interesse público ${ }^{17}$.

(KRUEGER, Guilherme. Os sonhos interrompidos e os rostos humanos nos serviços de saúde: a cooperação como um ato de preferência dos médicos e dos cirurgiões-dentistas». In: Aspectos jurídicos e econômicos das cooperativas de saúde. Guilherme Krueger e Lucila Carvalho Medeiros da Rocha (coord). Belo Horizonte: Del Rey, 2012, p. 32).

17 FORGIONI, Paula A. Os fundamentos do antitruste. 8. ed. São Paulo: Editora Revista dos Tribunais, 2015. pp. 199-203. As isenções em bloco são, portanto, situações de imunidade ao Sherman Act aplicadas a setores específicos da economia norte-ameri- 
No Brasil, conforme destaca Fernando de Magalhães Furlan ${ }^{18}$, o Estado pode realizar a apuração dos fatos e a condenação de cooperativas por infração à ordem econômica, posto que a atuação, neste aspecto, ocorre não como interferência no funcionamento -o que, na visão do autor, traria o pressuposto de «impedi-la de subsistir ou de exercer suas atividades»-, mas tão somente, a aplicação de sanção por ilícito praticado, nos termos estabelecidos pela ordem jurídica vigente. O resguardo da liberdade concorrencial, neste sentido, traduz-se em um dever que se sobrepõe à forma jurídica que é revestida a sociedade cooperativa e o sancionamento de condutas não reprimiria a liberdade de associação e não agrediria a imunidade constitucional concedida a elas, posto que essa imunidade apenas se restringiria «aos limites de sua existência e desenvolvimento» ${ }^{19}$.

Neste sentido, adotando a visão amplamente estabelecida pela doutrina antitruste brasileira, quanto à possibilidade de sancionamento das cooperativas, nos termos expostos, bem como na esteira da visão estabelecida por Furlan, temos, então, o primeiro limite ao equacionamento de sanções sobre cooperativas por atos contrários ao princípio da livre concorrência: as sanções não podem consistir em aplicação de penalidades que venham, direta ou indiretamente, interferir no desenvolvimento, estabilidade ou na própria existência da sociedade, diante do assento constitucional especial assegurado a esta espécie societária.

Aqui se insere a necessidade de pensar na finalidade do empreendimento cooperativo, ou seja, o que desencadeia sua própria constituição: a união de forças de pequenos agentes econômicos, com o escopo de competir em igualdade com os monopolistas originais. Por essa razão, não raras vezes, sustenta-se a existência de um poder com-

cana. Estão dentro do contexto que Paula Forgini denomina de «válvulas de escape» da legislação antitruste, que incluiria ainda a adoção da regra da razão (rule of reason), comum na tradição norte-americana; as isenções, conforme previsto na tradição da União Europeia, contidas nos artigos 101 e 102 do Tratado sobre o Funcionamento da União Europeia (TFUE); e as autorizações, geralmente adotadas pelo direito antitruste brasileiro. Todas estas «válvulas de escape» são utilizadas com vistas a propiciar ao intérprete da norma antitruste que a aplicação desta não gere efeitos contrários ao desejado, restringindo ao invés de possibilitar maior liberdade concorrencial. Ainda sobre a aplicação da legislação antitruste norte-americana sobre cooperativas, ver as consideradas realizadas por FRAZÃO, Ana. A sociedade cooperativa e o abuso do poder econômico. In: Sociedades cooperativas. Alfredo de Assis Gonçalves Neto (coord.). São Paulo: Lex, 2018, pp. 361-398.

18 FURLAN, Fernando de Magalhães. Questões polêmicas em Direito Antitruste. São Paulo: Lex Editora, 2004, p. 27.

19 FURLAN, Fernando de Magalhães. Questões polêmicas em Direito Antitruste. São Paulo: Lex Editora, 2004, p. 28. 
pensatório ou poder de barganha, com interação de forças para gerar ganhos de escala20. No Brasil, o debate sobre o poder compensatório é corrente dentro da jurisprudência do CADE e estudos desenvolvidos por Paulo Furquim de Azevedo e Silvia Fagá de Almeida apontam como característica da atuação das cooperativas dentro do mercado de saúde suplementar brasileiro, a realização de coordenação e integração de atividades que podem ocasionar concentração de poder no mercado, mas que não são aptas a gerar diretamente delitos de natureza concorrencial, diante, justamente, da existência de um poder compensatório para minimizar a assimetria de poder nas negociações ${ }^{21}$. Assim, o poder compensatório é um mecanismo autorregulador do mercado e não pode ser desprezado, sob pena de desencadear mais prejuízos do que melhoria ao interesse público.

Em continuidade à análise sobre a jurisprudência do CADE, verifica-se que mesmo diante das tentativas da autoridade antitruste brasileira em dissuadir a atuação das cooperativas, por vezes identificadas como anticompetitivas, as evidências encontradas na pesquisa, inicialmente levam à conclusão de que as sanções pecuniárias e a imposição de algumas obrigações de adequação do comportamento das cooperativas podem não ter tido o enforcement necessário para induzir a um parâmetro de adequação sobre o comportamento de outras cooperativas. Na análise dos votos e pareceres existentes nos processos administrativos de controle de condutas, é nítida a preocupação estatal sobre a eficácia das penalidades impostas, culminando em recomendações quanto à necessidade de uma aplicação mais incisiva de sancionamentos para atrair o ajustamento das condutas das cooperativas conforme os patamares de garantia plena da liberdade concorrencial e como mecanismo inibidor de novos ilícitos.

20 O economista John Kenneth Galbraith desenvolveu, em 1952, a teoria do poder compensatório, que consiste na organização de um poder de mercado para possibilitar uma resposta a outra posição de poder originário, o que funcionaria como um «freio» ao poder econômico (GALBRAITH, John Kenneth. Capitalismo americano: o conceito de poder compensatório. São Paulo: Novo Século, 2008, pp. 11-174).

$21 \mathrm{Na}$ análise, Azevedo e Almeida realizam estudo sobre os profissionais médicos e as cooperativas de trabalho, afirmando que o poder compensatório atua justamente para fazer frente às operadoras de planos de saúde, oferecendo maior poder aos médicos. Em conclusão, os autores afirmam que por meio do método econométrico de painel, no setor de saúde suplementar, a coordenação para definição da dimensão preço possui resultados positivos associados ao poder compensatório (AZEVEDO, Paulo Furquim de; ALMEIDA, Sílvia Fagá de. Cooperativas médicas: ilícito antitruste ou ganho de bem-estar?. FGV. 2010, pp. 01-20). 
Além das sanções pecuniárias, são aplicadas às cooperativas as sanções restritivas de direitos, denominadas também de remédios comportamentais, como a imposição de publicação da condenação em jornal indicado na decisão, proibição de contratar com o poder público e de participar de licitações, e imposição de obrigação de modificação estatutária. As sanções de natureza comportamental, estão previstas no art. 38 da Lei 12.529/2011. No entanto, maior controvérsia enfrenta a possibilidade de aplicação de sanções de natureza estrutural em cooperativas. Exemplificativamente, podem ser adotadas pela autoridade antitruste brasileira os seguintes remédios estruturais no âmbito do controle de condutas: mudanças na organização societária, como a imposição de cisão empresarial, venda de ativos (desinvestimentos), transferência de controle societário, entre outros ${ }^{22}$; dissolução compulsória da empresa (extinção de sua atuação no mercado); proibição de entrada de novos membros ${ }^{23}$; entre outros remédios, diante da tessitura aberta das sanções que podem ser aplicadas para o restabelecimento da ordem nos mercados ${ }^{24}$.

Sob o enfoque do controle de condutas, no Brasil são prevalecentes investigações que se processaram em desfavor de cooperativas que atuam no mercado de saúde suplementar. Quanto ao controle de estruturas, há uma grande diversidade de segmentos de mercados em que as cooperativas realizam atos de concentração com outras cooperativas ou com empresas mercantis, atos que perpassam desde a venda

22 Ressalte-se que o CADE salientou em oportunidades distintas a necessidade de determinação de desmembramento do empreendimento. Exemplificativamente, destaca-se o processo administrativo instaurado em desfavor da Cooperativa de Anestesiologistas do Rio Grande do Norte (COOPANEST/RN), em que foi determinada a cisão por meio de desfiliação voluntária e compulsória de cooperados, decisão que foi questionada na 4. ${ }^{a}$ Vara da Justiça Federal do Rio Grande do Norte, por meio da Ação Civil Pública n. ${ }^{\circ}$ 0011318-43.2008.4.05.8400. Em outra oportunidade também foi cogitada a aplicabilidade de cisão em relação a Cooperativa de Cirurgiões Cardiovasculares do Espírito Santo (Coopcardio/ES), P.A. n. ${ }^{\circ}$ 08012.010629/2007-15, que acabou assinando Termo de Compromisso de Cessação (Requerimento n. ${ }^{\circ}$ 08700.002867/2015-17), evitando a análise de mérito do processo administrativo.

23 Conforme exposto em nota técnica do processo da Coopcardio/ES (BRASIL. CADE. PA n. ${ }^{\circ} 08012.010629 / 2007-15$, p. 3102).

24 A exemplo do que ocorre no cenário do Direito Antitruste Europeu, verifica-se também a possibilidade de equacionar remédio estrutural que limite estrategicamente os investimentos da empresa, conforme pronunciamento expedido pela Comissão Europeia, no âmbito de investigação realizada no mercado de gás na Itália, no case ENI (ver MAIER-RIGAUD, Frank P.; HELLSTROM, Per; BULST, Friedrich Wenzel. Remedies in European Antitrust Law (May 3, 2011). Antitrust Law Journal, Vol. 76, pp. 43-63, 2009, p. 57). 
e compra de ativos, bem como a celebração dos mais diversos contratos de natureza mercantil.

Em razão do controle de condutas ser prevalecente na análise desse estudo, as anotações seguintes, referem-se notadamente sobre as principais condutas identificadas pelo CADE como praticadas por cooperativas dentro do território nacional.

\subsection{Controle de condutas}

O controle de condutas se revela como a necessidade de compreender e sancionar os comportamentos anticoncorrenciais adotados pelos agentes econômicos, que atualmente estão estruturados no artigo 34, incisos I a IV da Lei n. ${ }^{\circ}$ 12.529/2011, e consistem em atos que limitam, falseiam ou prejudicam a livre concorrência ou a livre iniciativa, que causa dominação de mercado relevante de bens ou serviços, que constitui aumento arbitrário dos lucros e que caracteriza exercício abusivo de posição dominante. Neste prisma, podem englobar quaisquer das condutas tipificadas pelo $\S 3 .^{\circ}$ do artigo 36 da lei antitruste, cuja tipificação extensiva pode ser justificada no fato de o Brasil não adotar um tratamento de proibição per se, devendo ser realizada uma análise caso a caso para verificar se a conduta causa ou não prejuízo à concorrência 25 .

Entre os precedentes de controle de condutas, as práticas mais comuns analisadas pelo CADE que envolvem sociedades cooperativas, referem-se a cartéis, acordos de exclusividade (unimilitância) ${ }^{26}$, limitar o acesso ou criar dificuldades de manutenção de outros concorrentes ao mercado, recusas de contratar, dificultar ou romper relações comerciais e imposição de tabelas de honorários ${ }^{27}$, sendo que as cooperati-

25 OLIVEIRA, Gesner; RODAS, João Grandino. Direito e economia da concorrência. 2. ed. rev. e atual. São Paulo: Revista dos Tribunais, 2013, p. 52.

26 Quanto a prática de unimilitância, de acordo com estudo realizado pelo CADE em 2015, foram analisados 155 processos administrativos que envolviam as cooperativas Unimed's, dos quais 102 resultaram em condenação (65,81\%), 14 foram arquivados $(9,03 \%)$ e em 39 processos houveram assinaturas de Termos de Cessação de Conduta $(25,16 \%)$, com a obrigação de exclusão da cláusula de exclusividade dos estatutos das cooperativas (BRASIL. CONSELHO ADMINISTRATIVO DE DEFESA ECONÔMICA. Mercado de Saúde Suplementar: condutas. Cadernos CADE. Brasília, 2015, p. 56).

27 Acerca da imposição de tabelas de honorários de serviços médicos, o CADE julgou entre junho/1996 a maio/2015, 81 processos, dos quais 73 resultaram em condenação e 08 foram arquivados. Paralelamente a estes casos também foi analisada a licitude da atuação de cooperativas como representante dos médicos, definindo valores homogêneos para todos os cooperados. Nesta hipótese, a análise da jurisprudência 
vas de trabalho médico, atuantes no mercado de saúde suplementar, são as que notoriamente possuem maior preponderância em condenações aplicadas pela autarquia. Portanto, são comuns condenações sobre todos os efeitos destacados pelo artigo 36 da Lei n. ${ }^{\circ}$ 12.529/2011 (correspondente aos artigos 20 e 21 da antiga lei antitruste - Lei n. ${ }^{\circ}$ 8.884/1994), por prejudicar a livre concorrência, aumentar arbitrariamente os lucros, exercer domínio de mercado relevante e por abusar da posição dominante, efeitos que podem ocorrer concomitantemente.

\subsubsection{CARTEL}

A prática de cartel por cooperativas ocorre quando efetivamente evidenciado o acordo para fins de domínio coordenado de determinados mercados, com vistas ao aumento da lucratividade, o que não se coaduna com a finalidade do cooperativismo, ou seja, prestar serviços aos associados, enquanto sociedades de pessoas e não de capital. No entanto, é necessário delinear que a simples união de trabalhadores de determinado segmento em uma cooperativa não caracteriza cartelização, mas sim uma mutualidade que evidencia a necessidade de buscar melhores condições de trabalho. Isto é o que se evidencia em processos em que houve a averiguação da prática de cartel no mercado de saúde suplementar ${ }^{28}$.

No entanto, em análise aos processos administrativos que resultaram em condenação pelo CADE sobre cooperativas do ramo agropecuário $^{29}$, verifica-se a existência de cartel clássico, que deve ser combatido,

do CADE, conforme estudo divulgado pela autarquia, entre os meses de junho/1996 a maio/2015, foram analisados 20 processos administrativos, cujo objeto eram condutas atribuídas a sociedades cooperativas de especialidades médicas. Na análise, 08 (oito) processos resultaram em condenações, em outros 08 (oito) foram celebrados Termos de Cessação de Conduta (TCC) e apenas 04 (quatro) processos resultaram em arquivamentos (BRASIL. CONSELHO ADMINISTRATIVO DE DEFESA ECONÔMICA. Mercado de Saúde Suplementar: condutas. Cadernos CADE. Brasília, 2015, pp. 27; 44).

28 Neste sentido, destacam Almeida e Azevedo, informando que as cooperativas médicas são arranjos para ganho de eficiência, o que no mercado de saúde suplementar se evidencia pela importância da negociação coletiva diante de fatores como forte presença de regulação, o que leva a concentração, e o grande poderio das operadoras de planos de saúde que, muitas vezes, não remuneram de forma justa a classe médica. A coordenação é destinada a equilibrar a assimetria de poder (ALMEIDA, Silvia Fagá de; AZEVEDO, Paulo Furquim. Cooperativas médicas: cartel ou legítima defesa?. In: Aspectos jurídicos e econômicos das cooperativas de saúde. Guilherme Krueger e Lucila Carvalho Medeiros da Rocha (coord). Belo Horizonte: Del Rey, 2012, pp. 167-192).

29 Ver os Processos Administrativos n. ${ }^{\circ} 08012.010744 / 2008-71$, 08700.000396/2016-85 e 08012.003893/2009-64. 
inclusive, pelos próprios organismos representativos do cooperativismo, tendo em vista o desvirtuamento dos objetivos do movimento.

Assim, observa-se que analisar a coordenação entre concorrentes não é tarefa simples na determinação de quando essa coordenação gera benefícios que devem ir além de cálculos econômicos, mas que evidenciem também ganhos sociais. Entretanto, é também imperativo o combate às pseudocooperativas, ou seja, aquelas que agem dispostas a colocar a obtenção de lucratividade e a precarização do trabalho como base de suas condutas. Estas não correspondem aos objetivos do movimento em sua gênese, bem como não se inserem dentro da extensão da proteção constitucional.

\subsubsection{ACORDOS DE EXCLUSIVIDADE}

Quanto às condutas que envolvem acordo de exclusividade, estas representam práticas restritivas verticais ${ }^{30}$, que dentre os casos analisados pelo CADE abrangem em grande número as cooperativas de trabalho médico, que impõem em seus estatutos sociais as chamadas "cláusulas de unimilitância», que preveem a fidelidade do cooperado, cuja adoção se justificaria, inicialmente, pela permissão contida no artigo 29 , §4. ${ }^{\circ}$ da Lei n. ${ }^{\circ}$ 5.764/1971 - Lei Geral do Cooperativismo31. Durante muito tempo, inclusive, os próprios tribunais pátrios asseguravam a legalidade de imposição de exclusividade aos associados de cooperativas de trabalho médico, sob o prisma puramente societário, sem adentrar nas especificidades de restrição à liberdade concorrencial advindas da prática32.

30 Ao contrário dos cartéis que são práticas restritivas horizontais, ou seja, que afetam concorrentes em um mesmo mercado, as práticas verticais envolvem diferentes mercados de uma mesma cadeia produtiva, relacionando-se diretamente com fornecedores, produtores e consumidores (OLIVEIRA, Gesner; RODAS, João Grandino. Direito e economia da concorrência. 2. ed. rev. e atual. São Paulo: Revista dos Tribunais, 2013, p. 52).

31 «Art. 29. O ingresso nas cooperativas é livre a todos que desejarem utilizar os serviços prestados pela sociedade, desde que adiram aos propósitos sociais e preencham as condições estabelecidas no estatuto, ressalvado o disposto no artigo 4 . $^{\circ}$, item I, desta Lei. [...] §4. ${ }^{\circ}$ Não poderão ingressar no quadro das cooperativas os agentes de comércio e empresários que operem no mesmo campo econômico da sociedade» (BRASIL, Lei $n{ }^{\circ} 5.764$ de 1971).

32 O Superior Tribunal de Justiça durante longo período manteve entendimento de que a cláusula de unimilitância possuía plena validade, conforme os posicionamentos adotados nos acórdãos do REsp 126391/SP (DJ 27/09/1999, p. 94), AgRg no REsp 685327/RS (DJ 17/10/2005, p. 292) e REsp 261155/SP (DJ 03/05/2004, p. 91). Saliente-se que o STJ, até então, não havia adentrado com profundidade ao tema re- 
Importante consideração acerca da exigência de exclusividade realizada pelas cooperativas de trabalho médico é realizada pelo ex-Conselheiro Paulo Furquim, no âmbito do processo que analisou a conduta da Unimed de Santa Bárbara D'Oeste e Americana ${ }^{33}$, em que é possível repensar o caráter de cooperação espontânea que deveria haver nas cooperativas, tendo em vista que, diante do fato do comportamento cooperativo muitas vezes não surgir naturalmente, as cooperativas veem-se obrigadas a criar «arranjos que restringem as ações individuais, que poderiam ser prejudiciais ao coletivo», o que é denominado na teoria econômica de comportamento free rider. Conforme destaca Paulo Furquim, a exigência de exclusividade também não é ilícito per se, uma vez que o prejuízo à liberdade concorrencial apenas acontece se o agente econômico possuir relevante poder de mercado.

A importância da temática ao longo dos anos tornou-se tão recorrente dentro do CADE, que ainda sob a vigência da antiga lei de defesa da concorrência — Lei n. ${ }^{\circ} 8.884 / 1994$ - a autarquia aprovou a Súmula n. ${ }^{\circ} 7$, que trata de aspectos de unimilitância relativos a cooperativas:

\section{Súmula n. ${ }^{\circ}$ 7. Publicada no D.O.U. de 09 de dezembro de 2009.}

Constitui infração contra a ordem econômica a prática, sob qualquer forma manifestada, de impedir ou criar dificuldade a que médicos cooperados prestem serviços fora do âmbito da cooperativa, caso esta detenha posição dominante ${ }^{34}$.

É importante evidenciar acerca da prática de unimilitância, algumas externalidades provenientes do mercado de saúde suplementar que não podem ser desprezadas, como a alta concentração do mercado, devido à forte regulação do setor, sendo necessário que os planos e seguros de saúde tenham uma quantidade razoável de profissionais e beneficiá-

lativo à agressão à livre concorrência. Por ocasião de apreciação de recurso interposto pela Unimed de Santa Maria, o ministro Humberto Martins, da 2. ${ }^{a}$ Turma do STJ, firmou em seu voto o entendimento de que "ao médico cooperado que exerce seu labor como profissional liberal, não se aplica a exigência de exclusividade do \& $4 .^{\circ}$ do art. 29 da Lei n. 5.764/71, salvo quando se tratar de agente de comércio ou empresário» (STJ, REsp 1172603/RS, DJe 12/03/2010). Neste sentido, o disposto no §4. ${ }^{\circ}$ do art. 29 da Lei 5764/71, não poderia ser aplicável aos profissionais liberais. Entendimento que foi

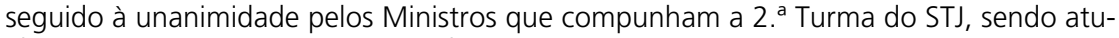
almente o posicionamento preponderante.

33 BRASIL. CADE. P.A. n. ${ }^{\circ} 08012.000629 / 2006-26$, pp. 462-463.

34 BRASIL. CONSELHO ADMINISTRATIVO DE DEFESA ECONÔMICA (CADE). Súmula n. ${ }^{\circ}$ 7, de 09 de dezembro de 2009. Diário Oficial da União de 14.12.2009 n. ${ }^{\circ}$ 238, Seção 1, p.51. 
rios, para a própria sustentabilidade financeira em pequenos mercados, cujos municípios geralmente possuem baixa densidade populacional. Neste sentido, estudos apontam a necessidade de a análise antitruste perquirir se a unimilitância praticada pelas cooperativas, notadamente as Unimed's e Uniodonto, não foram uma estratégia para compensar essas externalidades, necessárias para formar uma rede de provedores, principalmente em áreas não metropolitanas ${ }^{35}$. Tem-se, ainda, que estes acordos de exclusividade de prestação de serviços contêm a necessidade de definição precisa do mercado relevante ${ }^{36}$, tendo em vista que não é possível apenas pressupor que os agentes envolvidos na conduta possuam poder de mercado preponderante em dada região ${ }^{37}$.

De um modo geral a conduta das cooperativas de trabalho médico ao impor cláusula de exclusividade e, ao mesmo tempo, congregar a grande maioria dos profissionais existentes no mercado, conforme decisões do $C A D E$, acarreta prejuízo à livre concorrência, pois reforça o domínio de mercado por elas conquistado e exercício abusivo de posição dominante. Traz, ainda, o enquadramento típico aos atos de limitação do acesso de novas empresas no mercado, dificultando o funcionamento e o desenvolvimento de concorrentes (imposição de barreiras artificiais à entrada), impedindo o acesso de concorrentes a insumos que, neste caso, são os médicos enquanto profissionais.

35 GAMA, Marina Moreira da; ANDRANDE, Mônica Viegas; MAIA, Ana Carolina. A defesa da concorrência e a defesa do consumidor no setor de planos e seguros de saúde no Brasil. In: Aspectos jurídicos e econômicos das cooperativas de saúde. GuiIherme Krueger e Lucila Carvalho Medeiros Rocha (coord.). Belo Horizonte: Del Rey, 2012, pp.141-165.

36 A definição de mercado relevante, ao mesmo tempo que possui importância ímpar para a correta identificação do dano concorrencial sobre o mercado, também não apresenta facilidade de demonstração, tendo em vista que se revela como uma operação de delimitação e identificação das relações de concorrência, conforme destaca Paula Forgioni, para quem a própria operação é instrumental, com o intuito de aplicar a lei antitruste, valorando corretamente o comportamento do agente e as consequências deste comportamento sobre o mercado atingido (FORGIONI, Paula A. Direito concorrencial e restrições verticais. São Paulo: Revista dos Tribunais, 2007, pp. 86-89).

37 É recorrente nos processos analisados pelo CADE que envolvem condutas de unimilitância praticadas por cooperativas, a identificação de grande domínio de mercado. Aliás, a análise da posição dominante é um dos pressupostos para haver condenação, sendo este poder de mercado avaliado sob o prisma do «controle da mão-de-obra detida pela operadora e não o número de beneficiários do plano de saúde por ela comercializado». O cálculo do poder de mercado, portanto, leva em consideração os seguintes fatores: (i) o percentual de mercado da cooperativa; (ii) a quantidade de cooperados presentes na sociedade; e (iii) o quantitativo de médicos atuantes do mercado geográfico (BRASIL. CONSELHO ADMINISTRATIVO DE DEFESA ECONÔMICA. Mercado de Saúde Suplementar: condutas. Cadernos CADE. Brasília, 2015, p. 57). 
Em análise às decisões do CADE, revela-se de forma perceptível, nos pareceres e votos em processos que envolvem a cláusula de exclusividade impostas pelas cooperativas de trabalho, a tendência de afirmar que esta espécie societária muitas vezes é usada para «[...]burlar, fraudar a verdadeira relação entre os cooperados[...]» que muitas vezes, a exemplo das Unimed's, ocorre a identidade de atos desta sociedade com atos comuns a empresas de natureza mercantil, atribuindo a ela atuação na "[...] condição de patrão ou empregador que contrata com os médicos e/ou usuários à prestação de serviços de assistência à saúde[...]»38. Nos processos foi possível verificar a existência de claras considerações de que as sociedades cooperativas de trabalho médico, a exemplo da Unimed, exerceriam atividade comercial com nítida desobediência ao preceituado pelo art. 3..$^{\circ}$ da Lei n. ${ }^{\circ}$ 5.764/1971, ou seja, o pressuposto de não-lucratividade ${ }^{39}$. Todavia, não se pode concordar completamente com essas formulações.

Conforme vislumbrado no estudo inicial do cooperativismo, trata-se de movimento que se constitui em empreendimento societário, criado justamente para enfrentar as distorções do mercado e não se contrapõe a concorrência quando representa seus associados buscando melhores condições de negociação, e pelos seus aspectos societários, cuja propriedade é coletiva e com remuneração atrelada a valorização do trabalho, não é possível concluir que as cooperativas de trabalho médico são ou atuam como empresas mercantis.

\subsubsection{IMPOSIÇÃOO DE TABELA DE HONORÁRIOS}

Entre as condutas analisadas pela autarquia, destaca-se também a imposição de tabela de honorários por cooperativas de trabalho médico, notadamente as condutas envolvendo as Cooperativas de Anestesiologistas (COOPANEST's) que atuam em diversos Estados da Federação ${ }^{40}$. De acordo com informações do CADE, nos primeiros processos analisados pela autarquia no início da década de 1990, as condenações ocorriam sem análise das particularidades dos casos concretos. A exis-

38 Conforme destacado pelo Procurador Ricardo C. A. Meireles, no âmbito do Parecer n. ${ }^{\circ}$ 279/1997, no Processo Administrativo cuja representada foi a Unimed São João da Boa Vista.

39 Recomenda-se a análise do Processo Administrativo n. ${ }^{\circ} 08000.011866 / 1994-84$.

40 Recomenda-se a verificação dos processos administrativos relativos a conduta das COOPANESTS nos Estados do Ceará (BRASIL. CADE. P.A. n. ${ }^{\circ} 08012.003664 / 2001-92$ ), Bahia (BRASIL. CADE. P.A. n. $\left.{ }^{\circ} 08012.007042 / 2001-33\right)$, Pernambuco (BRASIL. CADE. P.A. n. $\left.{ }^{\circ} 08012.008060 / 2004-85\right)$, Paraíba (BRASIL. CADE. P.A. n. $\left.{ }^{\circ} 08012.007380 / 2002-56\right)$ e Goiás (BRASIL. CADE. P.A. n. ${ }^{\circ} 08012.000855 / 2010-93$ ). 
tência de tabela, de per se, era considerada ilícita em razão de a ação ser caracterizada como prática coordenada capaz de agredir a livre concorrência no mercado ${ }^{41}$.

No entanto, o atual entendimento do CADE em caso de tabelas de honorários médicos adotadas de forma individual pelo profissional, é pela possibilidade de adoção de forma sugestiva, com vistas à negociação com os demais agentes do mercado. As tabelas apenas não podem ser impostas em caso de utilização como referência nas relações contratuais ${ }^{42}$. Assim, o CADE considera como abusivas as práticas de coerção dos médicos que não aderem à tabela ou ao movimento de negociação conjunta, bem como os casos de recusa de negociação de forma desproporcional (paralisações por tempo indeterminado, ameaças de descredenciamento, entre outras).

Como caso representativo, acerca do tabelamento de preços e domínio de mercado, temos o processo administrativo que apurou os atos da Cooperativa dos Cirurgiões Cardiovasculares do Espírito Santo $(\text { COOPCARDIO-ES })^{43}$. Neste processo, merece destaque as considerações constantes da Nota Técnica n. ${ }^{\circ} 180$ da Superintendência-Geral do $C A D E$, que ressalta o fato de que a precificação e oferta de bens e serviços não pode ser considerado um ilícito per se, devendo ser analisados os impactos anticompetitivos.

Merece destaque, também, a análise evolutiva da atuação do CADE, realizada na mesma Nota Técnica n. ${ }^{\circ} 180$. O estudo revela que desde 2004, as COOPANEST's foram condenadas por influência de conduta uniforme quando detinham parcela substancial de mercado. No entanto, em 2005, notadamente na análise de condutas das COOPANEST's dos Estados do Ceará, Pará, Bahia e Pernambuco, dois pontos relevantes passam a ser abordados com maior profundidade: 1) a forma como é mensurada a possibilidade de exercício de poder de mercado das cooperativas em caso de multimilitância - o que resultou na absolvição das COOPANEST's dos Estados do Ceará e do Pará, mesmo detendo essas cooperativas grande poder de mer-

41 BRASIL. CONSELHO ADMINISTRATIVO DE DEFESA ECONÔMICA. Mercado de Saúde Suplementar: condutas. Cadernos CADE. Brasília, 2015, pp. 28-29.

42 BRASIL. CONSELHO ADMINISTRATIVO DE DEFESA ECONÔMICA. Mercado de Saúde Suplementar: condutas. Cadernos CADE. Brasília, 2015, pp. 27-28.

43 BRASIL. CADE. Processo Administrativo n. ${ }^{\circ} 08012.010629 / 2007-15$. A COOPCARDIO-ES estava sendo investigada por monopolizar o mercado de médicos cirurgiões no Estado do Espírito Santo, impor tabela de preços e descredenciamento coletivo no Sistema Único de Saúde (SUS) e da operadora SAMP Assistência Médica, configurando «abuso de poder com efeitos concorrenciais» (p. 3097). 
cado 44 ; 2) se é necessário analisar o poder de mercado de grandes planos de saúde e se o equilíbrio da negociação com estes agentes justificaria a criação de grandes cooperativas ${ }^{45}$.

Quanto ao primeiro ponto de discussão, o entendimento era de que a multimilitância abre a possibilidade de diminuição de poder de mercado da cooperativa e quanto ao segundo ponto de discussão, abre-se a tese do poder compensatório, levada à efeito pelo ex-Conselheiro Paulo Furquim, no âmbito do julgamento da conduta da COOPANEST/Bahia ${ }^{46}$, cujo entendimento é no sentido da possibilidade uniformização de conduta pela cooperativa, desde que preenchidas algumas condições: (1) identificação de assimetria nas negociações, em desfavor do prestador de serviço médico; (2) reconhecimento da interdependência entre ofertante e demandante, em contraposição ao exercício unilateral de poder de mercado; (3) inexistência de coação ou retaliação ao membros que realizam serviços por outras organizações; e (4) ausência de condição de exercício de poder de mercado 47 .

Entretanto, no mesmo processo em que apurou a conduta da COOPANET/Bahia, o ex- Conselheiro Ricardo Villas Bôas Cueva trouxe voto divergente, no sentido de que a existência de poder de mercado por parte das empresas tomadoras de serviços (planos de saúde) não é suficiente para aceitar a ação coordenada das cooperativas de trabalho médico, fixando preços e impedindo, portanto, sua formação natural pela competição no mercado. Seria necessária a adoção das chamadas «zonas de segurança» (antitrust safety zone), conforme utilizadas pelas autoridades antitruste norte-americanas (Federal Trade Comission e Department of Justice $)^{48}$. Uma vez que da análise resulte a conclusão de

44 As COOPANEST'S Ceará e Pará possuíam número muito superior de médicos inscritos como anestesiologistas nos Conselhos Regionais de Medicina dos Estados. No caso do Ceará $249 \%$ da lista do CRM e no caso do Pará, $276 \%$.

45 De acordo com publicação do CADE, a partir dos casos que envolviam as condutas das COOPANET's do Cerará, Pará, Bahia e Pernambuco, e das questões suscitadas nestes precedentes, houve uma nova compreensão da autarquia sobre o tratamento das cooperativas (BRASIL. CONSELHO ADMINISTRATIVO DE DEFESA ECONÔMICA. Mercado de Saúde Suplementar: condutas. Cadernos CADE. Brasília, 2015, p. 50).

46 BRASIL. CADE. PA n. ${ }^{\circ} 08012.007042 / 2001-33$.

47 Informações constantes da Nota Técnica n. ${ }^{\circ} 180$, presente no P.A. n. ${ }^{\circ} 08012.010629 / 2007-15$, p. 3087.

48 De acordo com a adoção das chamadas «zonas de segurança», há um roteiro pré-determinado de análise, conforme voto do ex-Conselheiro Ricardo Cueva: "Segundo o roteiro, não provocarão preocupações concorrenciais, salvo em casos extraordinários, aquelas joint ventures que: possuindo exclusividade, seus participantes compartilhem riscos financeiros e representem 20\% (vinte por cento) do mercado relevante 
que a conduta não se enquadra na "zona de segurança», para o exConselheiro seria necessária a análise do caso pela regra da razão, seguindo quatro etapas:

1) definição de mercado relevante; 2) avaliação dos efeitos competitivos da «joint venture» (assim tratada nos EUA as sociedades que aqui se aproximariam das cooperativas médicas) - examinam-se a estrutura e as atividades da associação dentro do mercado relevante, centrando-se em dois aspectos principais: (i) poder de aumentar preços acima do nível competitivo e (ii) poder de impedir ou excluir concorrentes do mercado; 3) avaliação das eficiências geradas para o mercado; 4) avaliação da existência de outros acordos ou condições para determinar se necessários para alcançar as eficiências pretendidas ${ }^{49}$.

A mesma racio decidendi adotada pelo ex-Conselheiro Paulo Furquim, foi retomada no âmbito do Processo Administrativo que analisou a conduta da FEMCOM - Federação Mineira de Cooperativas Médicas (atual FENCOM), cuja relatoria foi da ex-Conselheira Ana Frazão ${ }^{50}$, que apurou a prática de imposição de preços de honorários médicos através da Tabela de Classificação Brasileira Hierarquizada de Procedimentos Médicos (CBHPM). A Conselheira-relatora afastou a aplicação da teoria do poder compensatório neste caso específico para a FEMCOM ${ }^{51}$.

geográfico; não possuindo exclusividade, seus participantes compartilhem riscos financeiros e representem 30\% (trinta por cento) ou menos do mercado relevante geográfico» (BRASIL. CADE. Processo Administrativo n. ${ }^{\circ} 08012.007042 / 2001-33$ ).

49 Informações constantes da Nota Técnica n. ${ }^{\circ} 180$, presente no P.A. n. ${ }^{\circ}$ 08012.010629/2007-15, p. 3088. Destaque-se que posteriormente, o ex-ConseIheiro Paulo Furquim, no âmbito do P.A. n. ${ }^{\circ} 08012.002706 / 2009-25$, em que foi analisada a conduta de uma entidade não cooperativa, a empresa SERVAN-Anestesiologia e Tratamento de Dor de Campo Grande/MS, seguiu este entendimento divergente do ex-Conselheiro Ricardo Villas Bôas Cueva, posicionando-se: "[...] a formação de associações e sociedades não caracteriza por si só um ilícito. Filio-me ao entendimento apontado pelo Conselheiro Cueva, de que há necessidade de se avaliar o grau de integração da sociedade, bem como o seu exercício no mercado. Se o grau de integração se avalia pela estrutura contratual da sociedade, o exercício há de observar os parâmetros tradicionais de uma análise concorrencial, a qual tem em conta desde o percentual de mercado até as eficiências da 'associação' (Mantido destaque do texto original).

50 BRASIL. CADE. Processo Administrativo n. ${ }^{\circ} 08012.005101 / 2004-81$.

51 No entanto, é importante ressaltar que a ex-Conselheira Ana Frazão demonstrou em outras oportunidades certa preocupação com a necessidade de verificar caso a caso a ocorrência de poder compensatório, pois "a união de agentes econômicos para compensar eventual assimetria de poder poderia afastar a ilicitude da conduta», conforme destaca em seu voto no processo em que analisa a conduta da FEMCOM e demais representados, bem como também delineado no âmbito do P.A. 
No mesmo processo, também em voto-vogal, o Conselheiro Gilvandro Vasconcelos Coelho de Araújo sustentou a tese de que o mercado de saúde suplementar em razão da sua estrutura, não aceita a aplicação do argumento do poder compensatório, bem como, mesmo se realizada a sua adoção para efeito de mitigar a conduta, a existência de poder de barganha não afastaria a ilicitude «em razão da responsabilidade objetiva adotada pela lei antitruste» ${ }^{52}$.

$\mathrm{Na}$ análise da conjuntura dos argumentos até o momento evidenciados, percebe-se a necessidade do correto delineamento e compreensão do que são os atos praticados pelas cooperativas de trabalho médico que podem ser considerados atos de natureza cooperativa (atos internos) e atos não-cooperativos (externos), para fins, inclusive, de aplicação justa das normas concorrenciais, reconhecendo a existência de um poder compensatório intrínseco aos atos cooperativos.

$\mathrm{O}$ ato cooperativo não abrange prática de negócio, não implica operação de mercado, nem contrato de compra e venda, é definido hodiernamente como ato praticado entre cooperativa e cooperado ou entre cooperativas, na busca de realizar os objetivos descritos no estatuto social das cooperativas, por isso é também denominado de ato interno. Assim, a sociedade cooperativa é uma sociedade de natureza instrumental, cujos atos cooperativos são aqueles inerentes à prestação

n. ${ }^{\circ}$ 08012.014463/2007-14, que possuía como uma das representadas a Unimed Goiânia, em que a Conselheira proferiu voto em consonância com a tese abordada pelo exConselheiro Paulo Furquim no P.A. n. ${ }^{\circ}$ 08012.007042/2001-33. Para Ana Frazão, justifica-se a excludente do poder compensatório quando esta for «uma opção de proteção que, como o próprio nome diz, deve estar sujeita à livre escolha por parte do beneficiado», o que não é o caso do P.A. n. ${ }^{\circ}$ 08012.005101/2004-81, tendo em vista a exigência de adoção compulsória da tabela de honorários da CBHPM, inclusive com imposição de sanção disciplinar em caso de descumprimento.

52 Entendimento também adotado pelo Conselheiro Gilvandro Vasconcelos Coelho de Araújo, por ocasião da análise do P.A. n. ${ }^{\circ}$ 08012.003048/2003-01, cujas representadas não eram cooperativas, mas sim entidades de classe: Sindicato dos Médicos do Estado do Ceará; Conselho Regional de Medicina do Estado do Ceará e Associação Médica Cearense. Entretanto, ressalte-se que o fundamento exposto pelo Conselheiro Gilvandro Vasconcelos Coelho de Araújo, quanto a responsabilidade por ilícito antitruste ser de natureza objetiva, não é de consenso na doutrina, apesar de ser tese prevalecente dentro do CADE. A ex-Conselheira Ana Frazão, inclusive, ressalta na sua relatoria do processo contra a FENCOM, a indispensabilidade do juízo sobre a culpa para avaliar a reprovabilidade da conduta na caracterização de infrações de natureza administrativa, notadamente em função do caráter sancionador do processo previsto na legislação antitruste, diretamente relacionado ao poder punitivo estatal. A mesma visão é exposta pela ex-Conselheira, na obra: FRAZÃO, Ana. Direito da Concorrência: pressupostos e perspectivas, São Paulo: Saraiva, 2017, p. 259-273. 
de serviço desta aos seus associados, possui, portanto, natureza institucional53.

A exata compreensão do ato cooperativo é crucial e necessária para subsidiar a análise e aplicação da legislação antitruste, sendo que esta deve ser vista com absoluta parcimônia sobre os atos internos (cooperativos), notadamente, aqueles atos que implicam em ofertar melhores condições aos profissionais-médicos cooperados, com mecanismos que possibilitem uma inserção justa destes no mercado de trabalho.

\subsubsection{RECUSAS DE CONTRATAR}

Destaca-se nas análises dos julgados do CADE, também atos que envolvem os chamados «boicotes», com recusas de contratar em massa, que ocorrem sobre duas vertentes: de maneira extracontratual e de maneira contratual. Na primeira hipótese, evidenciaram-se paralisações coletivas de atendimento médico, por prazo determinado ou não, o que o CADE tem aceitado desde que a paralisação não afete o atendimento aos pacientes e que ocorra por período determinado e curto. Quanto ao boicote contratual, ou seja, que ocorre com descredenciamento em massa de médicos, a autarquia tem determinado a condenação das pessoas jurídicas que a realizam por inviabilizarem, muitas vezes, totalmente os planos de saúde, o que inverteria o poder de barganha a favor dos médicos ${ }^{54}$.

A título exemplificativo, caso paradigmático envolveu 7 (sete) cooperativas, além de outras pessoas jurídicas, no Estado do Espírito Santo, conforme denúncia formulada pelo Ministério Público Estadual ${ }^{55}$. No âmbito do processo administrativo que apurou a conduta das cooperativas, verificou-se que estas buscavam monopolizar os serviços, cooptando parcela significativa dos médicos do Estado do Espírito Santo; praticavam a unimilitância; promoviam a suspensão de prestação de serviços médicos e paralisações de forma abusiva, que foram levadas a efeito com a não renovação de contratos, cujo objetivo era aumentar o poder de barganha para negociação de maiores valores remuneratórios; bem como dificultavam, sobremaneira, a viabilidade de concursos públicos (boicotes) para os cargos de médicos a nível estadual, nas mais diversas especialidades, o que configurou, nos termos do voto do Con-

53 NASCIMENTO, Carlos Valder do. Teoria geral dos atos cooperativos. São Paulo: Malheiros, 2007, pp. 52-73.

54 BRASIL. CONSELHO ADMINISTRATIVO DE DEFESA ECONÔMICA. Mercado de Saúde Suplementar: condutas. Cadernos CADE. Brasília, 2015, p. 37.

55 Trata-se do Processo Administrativo n. ${ }^{\circ}$ 08012.003706/2000-98. 
selheiro-relator, "sério desvio de finalidade» do cooperativismo, tendo as cooperativas utilizado, inclusive, de ações populares para impedir a realização dos concursos públicos.

Destaque-se que, conforme as demais condutas anteriormente descritas, não é um ilícito per se as mobilizações no sentido de melhorar a condição de trabalho e a remuneração pela prestação de serviços médicos. Conforme ressalta o Parecer Jurídico da Procuradoria Federal, presente no referido processo, na situação de pequenas cooperativas que não detém poder de mercado, é aceitável as mobilizações tendentes a conseguir melhor poder de barganha. Entretanto, diante da existência de posição monopolística, tais atos podem acarretar distorções e problemas concorrenciais, podendo resultar, no caso dos boicotes, em prejuízo significativo à população que precisa do atendimento médico gratuito, por meio do Sistema Único de Saúde (SUS). Assim, para o CADE, a necessidade de sancionar conduta como os boicotes, incluindo as recusas de contratar, reveste-se não só de proteção à concorrência, mas também aos consumidores, que não podem ser prejudicados pelas consequências de negociações coletivas ${ }^{56}$.

Assim, verifica-se da jurisprudência do CADE que a atenção maior sobre cooperativas de trabalho médico que atuam no mercado de saúde suplementar se deve a grande participação ${ }^{57}$, posto que conforme estudo divulgado pela autarquia, as cooperativas médicas detêm 36,94\% de participação na operação de planos de saúde no Brasil, considerando o número de beneficiários associados a cada tipo de operadora de plano de saúde, que envolve um mercado em que, além das cooperativas, também há atuação de sociedades em regime de autogestão, filantrópicas, seguradoras especializadas em saúde e empresas de medicina de grupo, mas nenhuma delas possui participação superior às cooperativas ${ }^{58}$.

56 BRASIL. CONSELHO ADMINISTRATIVO DE DEFESA ECONÔMICA. Mercado de Saúde Suplementar: condutas. Cadernos CADE. Brasília, 2015, p.37.

57 Neste sentido é importante ressaltar os estudos de Silvia Fagá de Almeida e de Paulo Furquim de Azevedo sobre o mercado de saúde suplementar brasileiro: AZEVEDO, Paulo Furquim de; ALMEIDA, Sílvia Fagá de. Cooperativas médicas: ilícito antitruste ou ganho de bem-estar?. FGV. 2010; e ALMEIDA, Silvia Fagá de. Poder compensatório e política de defesa da concorrência: referencial geral e aplicação ao mercado de saúde suplementar brasileiro. FGV, 2009.

58 BRASIL. CONSELHO ADMINISTRATIVO DE DEFESA ECONÔMICA. Mercado de Saúde Suplementar: condutas. Cadernos CADE. Brasília, 2015, pp. 13-14. O alto índice de concentração do mercado de saúde suplementar é demonstrado pelo fato de que em 2015 as 10 maiores empresas atuantes possuem 70\% do total de beneficiários, outras mais de mil operadoras dividem os outros $30 \%$ do mercado. 
Além disso, as relações e conflitos entre prestadores de serviços e operadoras não receberam a atenção necessária no marco regulatório do setor, muitas questões importantes ainda são decididas pelas autoridades antitruste, inclusive, o crescente «movimento de concentração e integração vertical» de operadoras de planos de saúde e demais agentes que atuam no mercado de saúde suplementar no Brasil, notadamente, por meio do controle de estruturas ${ }^{59}$.

Têm-se, ainda, os conflitos remuneratórios entre médicos e operadoras, que recaem, conforme acima demonstrado, sob a análise do controle de condutas, sendo necessário pensá-lo, no entanto, também sob o enfoque de uma necessidade de valorização do trabalho, combatendo a não-precarização e possibilitando a melhoria dos atendimentos médicos, inclusive, no âmbito do Sistema Único de Saúde (SUS), diante das constantes reivindicações da classe pela justa remuneração dos procedimentos públicos.

\section{A medida de intervenção estatal}

No decorrer do estudo verificamos que o processo antitruste se realiza como importante mecanismo de intervenção estatal para situações de abuso do poder econômico, através de atuações impositivas com fundamento no interesse público. Neste sentido, é indiscutível sua importância em contexto econômico e social para combater o domínio de mercado. Entretanto, é importante não olvidar que as intervenções realizadas para a defesa da concorrência precisam ser pensadas com parcimônia para não resultarem em danos sociais e prejuízos societários irremediáveis. A efetividade das medidas de intervenção também deve estar atenta aos parâmetros de razoabilidade e proporcionalidade.

Em relação às sociedades cooperativas, existe a necessidade de estabelecer como parâmetro que, em razão da própria finalidade da sua constituição - prestar serviços aos associados, o que implica na representação dos interesses dos membros dentro do mercado, como mecanismo de barganha-, que a análise antitruste deve partir da premissa de que a Constituição Federal de 1988 traçou a necessidade de um olhar diferenciado para o cooperativismo, e este tratamento diferenciado não enseja tratamento favorecido ou imunidade à legislação an-

59 BRASIL. CONSELHO ADMINISTRATIVO DE DEFESA ECONÔMICA. Mercado de Saúde Suplementar: condutas. Cadernos CADE. Brasília, 2015, p. 26. 
titruste, mas sim um tratamento que permita um equacionamento das sanções com atenção ao modelo de negócio sui generis em objetivos de constituição, propriedade, gestão e função social. Compreender essas peculiaridades, é o primeiro passo para identificar a exata medida da necessidade e adequação da intervenção.

Sustenta-se em conjunto com este entendimento, também o imperativo de efetivação de mecanismos que possibilitem uma maior participação dos regulados/investigados, mesmo que a intervenção administrativa tenha uma natureza de tradicional exercício do poder de polícia estatal ${ }^{60}$. Sob o prisma da participação das cooperativas investigadas, esta abrange a possibilidade de obtenção e divulgação de um conhecimento prévio e preciso não apenas do paradigma do mercado, mas da própria especificidade societária. Nesse sentido, conforme enfoque deste estudo, esse pensar os mecanismos de penalização e dissuasão de práticas abusivas deve ganhar características distintivas ${ }^{61}$.

A análise antitruste também não pode se descurar do entendimento sobre a dimensão e alcance do ato cooperativo. O estudo aprofundado sobre o correto enquadramento jurídico do termo ato cooperativo, foge ao escopo deste trabalho, mas não escapa à necessidade de melhor compreensão do fenômeno relacional entre cooperativa e cooperado, inclusive, para fins de melhor delineamento das relações decorrentes dos atos negociais ou de simples transferência de recursos realizados entre os sujeitos cooperados e sua cooperativa e vice-versa. A base de identificação está no olhar sobre quais são os serviços prestados ao cooperado, notadamente, sob o prisma de defesa e represen-

60 A participação aqui recomendada vai além da observância das garantias constitucionais do contraditório e da ampla defesa, que em todas as hipóteses devem ser aplicadas de forma plena, mas possibilita, sobretudo, uma abertura para a construção de um processo de cooperação entre autoridade e cooperativa, sempre que possível, para o encontro da efetividade de uma intervenção pensada em um patamar que não seja meramente impositivo.

61 Destaca-se, neste sentido, o artigo 101, item 3 do Tratado sobre o Funcionamento da União Europeia (TFUE), que prevê a isenção de aplicação da legislação a algumas atividades «que contribuam para melhorar a produção ou a distribuição dos produtos ou para promover o progresso técnico ou econômico», desde que não haja imposição desarrazoadas de restrições às empresas concorrentes e que o objetivo de melhorar a produção, distribuição ou promoção técnica-econômica não eliminem a concorrência quanto a uma parte substancial dos produtos em causa. Apesar de não existir isenção ampla às sociedades cooperativas, o TFUE consagra estas dimensões em que a isenção pode ser efetivada (BANCO CENTRAL EUROPEU. Tratado sobre o funcionamento da União Europeia. Jornal Oficial da União Europeia, 26 de outubro de 2012. Disponível em: <https://www.ecb.europa.eu/ecb/legal/pdf/c_32620121026pt.pdf>. Acesso em 19.08.2017, pp. 88-89). 
tação deste no mercado, para além da simples transferência de mercadorias e serviços.

A correta identificação do ato cooperativo pela autoridade antitruste, possibilita uma análise sobre as condutas que, inicialmente, podem ser identificadas como anticoncorrenciais, mas que em um exame aprofundado, podem ser atos lícitos de representação de interesses legítimos dos cooperados dentro do mercado, atraindo a aplicação de teses como a teoria do poder compensatório, já tão debatida dentro da jurisprudência do CADE, conforme se verificou anteriormente.

Diante disso, sustenta-se a impossibilidade da união de agentes econômicos em uma cooperativa ser considerada uma afronta à concorrência per se. A coordenação de agentes econômicos dentro uma cooperativa é ato plenamente lícito, posto que essa é finalidade precípua dessa espécie societária. Neste sentido, é necessária uma meIhor compreensão dos objetivos cooperativistas e da atuação destas no mercado.

Neste prisma, estabeleceu-se três parâmetros como alternativas à análise da autoridade antitruste brasileira, que podem ser aplicadas tanto para situações de controle de condutas, como de controle de estruturas, conforme a discricionariedade que é inerente às decisões administrativas:

1. Análise do ramo de atuação da cooperativa e das peculiaridades regulatórias ${ }^{62}$ : com uma visão que deve estar aliada a uma melhor definição e análise do mercado relevante, incluindo custos de manutenção no mercado, melhor delineamento e estudo da dimensão geográfica de atuação da cooperativa, compreensão de que as cooperativas se instalam em locais onde, muitas vezes, as sociedades empresárias não possuem interesse em se estabelecer;

62 Notadamente, diante da grande quantidade de casos julgados pelo CADE no mercado de saúde suplementar em que havia o envolvimento de cooperativas, considerando a necessidade de análise do ramo de atuação e regulação nele existente, destacam-se os estudos de Azevedo e Almeida, quanto a tese do poder compensatório (AZEVEDO, Paulo Furquim de; ALMEIDA, Sílvia Fagá de. Cooperativas médicas: ilícito antitruste ou ganho de bem-estar? FGV. 2010, pp. 3-6). No mesmo sentido, merece destaque também as peculiaridades ressaltadas por Ana Frazão, quanto ao mercado de saúde suplementar, em que afirma a necessidade da defesa da concorrência refletir sobre os efeitos concretos das atividades das cooperativas e de sua atuação em situação de monopólios (FRAZÃO, Ana. Direito da concorrência: pressupostos e perspectivas. São Paulo: Saraiva, 2017, pp. 350-361). 
2. Tipo de ato realizado pela cooperativa (ato cooperativo puro versus ato não-cooperativo)63: tratando-se de ato cooperativo a análise deve ser realizada, segundo parâmetro de discursividade e cooperação entre CADE, cooperativa investigada e demais stakeholders ${ }^{64}$, tendo em vista a melhor compreensão do que seria o ato cooperativo de acordo com o ramo de atividade, equacionando a melhor solução para a possível agressão à liberdade concorrencial. Ressalte-se que no ato cooperativo se insere a própria finalidade de constituição da cooperativa, o que delineia, inclusive, as características de propriedade e gestão do empreendimento. Em caso de controle de condutas, uma vez verificado que o ato praticado não se insere no conceito de ato cooperativo, o sancionamento deverá ser realizado com base na prática de ato de mercado comum, sem qualquer benefício;

3. O porte-econômico da sociedade cooperativa: apesar de estar contido o mandamento de verificação da situação econômica do infrator no art. 45, VII da Lei n. ${ }^{\circ}$ 12.529/2011, verifica-se que na prática jurisprudencial do CADE quase inexistem efeitos concretos deste balizamento, quando realizado65; em situações de controle de condutas, poucas vezes existe referência quanto à diminuição, por exemplo, de valores de multas ou redução, inaplicação de determinada penalidade restritiva de direito, em função do menor porte do empreendimento cooperativo.

63 Neste estudo, optou-se, inicialmente, como referência de conceituação a abordagem tradicional legislativa para o ato cooperativo, também utilizada em âmbito do Direito Tributário, que não está imune a críticas, mas estabelece segurança à autoridade antitruste e previsibilidade à cooperativa. Entretanto, não dispensando a necessidade de uma melhor compreensão do ato cooperativo em cada ramo do cooperativismo, mediante uma análise dos atos que importam na gênese de manutenção da atividade de cooperação dentro do mercado em que está estruturada.

64 Incluem-se além de potenciais relações jurídicas consumeristas e comerciais, também o contexto de participação dos órgãos representativos do cooperativismo em âmbito estadual e nacional, bem como de eventuais agências reguladoras, tratando-se de mercado regulado, bem como o pronunciamento da sociedade civil organizada, que desejar voz ativa no âmbito do processo administrativo antitruste.

65 Neste sentido, André Marques Gilberto destaca em pesquisa realizada na jurisprudência do CADE, ainda sob a égide da antiga lei antitruste, que, muitas vezes, a autoridade antitruste não realizava o exame da situação econômica do ofensor. Em exame dos requisitos que tratam da dosimetria da pena, nem sempre os analisa em completude, bem como que a tendência ao longo dos anos foi de simples aumento das sanções, inclusive, as de natureza pecuniária (GILBERTO, André Marques. O processo antitruste sancionador. Dissertação de mestrado. USP. São Paulo: 2008, pp. 245-246). 
Assim, os parâmetros alçados neste estudo como alternativos, mas que estão intimamente relacionados ao sistema de dosimetria de aplicação de penalidades pela autoridade antitruste, podem diminuir a assimetria de informações e, ao mesmo tempo, dois riscos incipientes: a inefetividade das medidas adotadas pela autoridade (inexistência de poder dissuasório) e as possíveis ineficiências ao empreendimento cooperativo e ao próprio mercado em que ela desenvolve suas atividades, diante de uma intervenção desproporcional.

\section{Conclusão}

$\mathrm{Na}$ análise realizada foi possível verificar problemas significativos para ambos os lados, autoridade antitruste e cooperativas. Entre os desafios da análise antitruste sobre atividades desempenhadas por cooperativas, destaca-se a compreensão de que alguns atos por estas praticados no mercado importam no exercício da própria finalidade da cooperativa (prestar serviço ao cooperado). Também se destaca a dificuldade de encontrar a correta dosimetria na aplicação de penalidades, segundo os critérios estabelecidos pela legislação, objetivando gerar o efeito dissuasório esperado.

O estudo optou por não abordar todas as formas de sancionamento permitidas pela legislação brasileira e aplicadas sobre cooperativas, objetivou apenas a análise sobre as decisões proferidas pela autoridade antitruste brasileira, acerca do entendimento dos atos praticados pelas cooperativas que importam em condutas anticompetitivas. Sustenta-se aqui, que a correta aplicação da legislação antitruste perpassa a compreensão efetiva da própria finalidade da cooperativa e suas características de propriedade e gestão, para assim estabelecer o acerto na identificação da necessidade e proporcionalidade do sancionamento.

Tal compreensão é necessária para um melhor tratamento das cooperativas enquanto operadores econômicos, com o cumprimento da exata compatibilização da garantia de mínima intervenção nas sociedades cooperativas (art. 5. ${ }^{\circ}$, inciso XVIII, CF/88), do estímulo estatal ao cooperativismo (art. 174, §2. ${ }^{\circ}, \mathrm{CF} / 88$ ) e, ao mesmo tempo, assegurar a livre concorrência nos mercados, reprimindo os abusos (art. 173, §4. , CF/88). O ponto de partida está na evidência científica de que interpretações equivocadas da lei antitruste podem conduzir a ineficiências. Nesse sentido, ambos os lados —autoridade antitruste e cooperativas- devem estar conscientes dos papéis de cada um dos sistemas de proteção da concorrência. 
O próprio direcionamento interpretativo também pode ser permeado pelos fundamentos da própria filosofia do movimento cooperativo, não podendo este modelo societário se valer do argumento de limites interventivos para a prática de atos ilícitos ou de condutas que infringem os princípios básicos do cooperativismo cuja centralidade está amparada em um arcabouço ético e moral secular.

É preciso evidenciar que a manutenção de um mercado sadio e equilibrado também é importante ao próprio cooperativismo e, em relação a isso, as cooperativas não devem se contrapor. Em seu histórico foram criadas justamente por trabalhadores e profissionais dos mais diversos segmentos, desejosos de competir com igualdade frente a monopolistas originais, atuando no sentido contrário às grandes forças do capital. Se cooperação inicialmente pode parecer o oposto de competição; em essência, podem ser efetivados em conjunto e de forma complementar, combatendo a competição desleal, com a valorização do trabalho humano.

Assim, a contribuição desta pesquisa está na abertura de um debate mais amplo. Na afirmação da necessidade de ir além das discussões entre o mínimo e o máximo de intervenção sobre cooperativas. É preciso compreender a necessidade de possibilitar canais institucionais e procedimentais que garantam que os objetivos cooperativistas e os objetivos de proteção da livre concorrência sejam compatibilizados.

\section{Bibliografia}

Almeida, Silvia Fagá de; Azevedo, Paulo Furquim de. Cooperativas médicas: cartel ou legítima defesa? In: Aspectos jurídicos e econômicos das cooperativas de saúde. Guilherme Krueger e Lucila Carvalho Medeiros da Rocha (coord.). Belo Horizonte: Del Rey, 2012, pp. 167-192.

Azevedo, Paulo Furquim de; Almeida, Sílvia Fagá de. Cooperativas médicas: ilícito antitruste ou ganho de bem-estar? FGV. 2010, pp. 01-20. Disponível em: <http://bibliotecadigital.fgv.br/dspace/handle/10438/6894>. Acesso em: 20 jan. 2020.

Banco Central Europeu. Tratado sobre o funcionamento da União Europeia. Jornal Oficial da União Europeia, 26 de outubro de 2012, pp. 88-89. Disponível em: <https://www.ecb.europa.eu/ecb/legal/pdf/c_32620121026pt. pdf>. Acesso em: 19 ago. 2016, pp. 88-89.

BIALOSKORSKI Neto, Sigismundo. EConomia e gestão de organizações cooperativas. 2. ed. São Paulo: Atlas, 2012, pp. 7-100.

BrASIL. Lei $n .{ }^{\circ} 5.764$ de 16 de dezembro de 1971. Define a política nacional de cooperativismo, institui o regime jurídico das sociedades cooperativas, e dá outras providências. Brasília. 1971. Disponível em: <https://www.planalto. gov.br/ccivil_03/leis/15764.htm>. Acesso em 20 jul. 2020. 
- Constituição da República Federativa do Brasil de 1988. Brasília. 05 out. 1988. Disponível em: <http://www.planalto.gov.br/ccivil_03/Constituicao/ ConstituicaoCompilado.htm>. Acesso em 03 jul. 2020.

—, Lei n. ${ }^{\circ} 12.529$ de 30 de novembro de 2011. Estrutura o sistema brasileiro de defesa da concorrência; dispõe sobre a prevenção e repressão às infrações contra a ordem econômica. 2011. Disponível em: <http://www. planalto.gov.br/ccivil_03/_Ato2011-2014/2011/Lei/L12529.htm>. Acesso em: 04 set. 2020.

—, Superior Tribunal de Justiça. Recurso Especial n. ${ }^{\circ} 1172603 / R S .2 .^{\text {a }}$ Turma. Recorrente: Conselho Administrativo de Defesa Econômica. Recorrida: Unimed Santa Maria. Relator: Min. Humberto Martins. DJe. 12 mar. 2010. Disponível em: <https://ww2.stj.jus.br/processo/pesquisa>. Acesso em: 26 ago.2017.

- Conselho Administrativo de Defesa Econômica (CADE). Resolução n. ${ }^{\circ} 20$, de 09 de junho de 1999. Anexo I. CADE. 1999. Disponível em: < http:// www.cade.gov.br/assuntos/normas-e-legislacao/resolucao/resolucao-no-20 -de-9-de-junho-de-1999.pdf/view>. Acesso em: 20 ago. 2020.

- Conselho Administrativo de Defesa Econômica (CADE). Mercado de Saúde Suplementar: condutas. Cadernos CADE. Brasília: CADE, 2015, p.13-57. Disponível em: <http://www.cade.gov.br/acesso-a-informacao/publicacoesinstitucionais/dee-publicacoes-anexos/copy_of_cadernos-do-cade-2013mercado-de-saude-suplementar-condutas-2013-2015.pdf>. Acesso em: 06 set. 2020.

- Conselho Administrativo de Defesa Econômica (CADE). Súmula $n .^{\circ} 7$, de 09 de dezembro de 2009. Diário Oficial da União de 14.12.2009 n. ${ }^{\circ} 238$, Seção 1, p. 51. Disponível em: <http://www.cade.gov.br/assuntos/assuntos/ normas-e-legislacao/normas_legislacao/sumulas-do-cade>. Acesso em 20 ago. 2020

ForglonI, Paula A. Direito concorrencial e restrições verticais. São Paulo: Revista dos Tribunais, 2007, pp. 86-89.

-, Os fundamentos do antitruste. 8. ed. São Paulo: Editora Revista dos Tribunais, 2015, pp. 199-203.

FrazÃo, Ana. Direito da concorrência: pressupostos e perspectivas. São Paulo: Saraiva, 2017, pp. 259-361.

- A sociedade cooperativa e o abuso do poder econômico. In: Sociedades cooperativas. Alfredo de Assis Gonçalves Neto (coord.). São Paulo: Lex, 2018, pp. 361-398.

FurLan, Fernando de Magalhães. Questões polêmicas em Direito Antitruste. São Paulo: Lex Editora, 2004, pp. 27-28.

GalbRAITH, John Kenneth. Capitalismo americano: o conceito de poder compensatório. Título original: American Capitalism: the concept of countervailing power. 1952. Tradução: Clara A. Colotto. São Paulo: Novo Século, 2008, pp. 11-174.

Gama, Marina Moreira da; Andrande, Mônica Viegas; MalA, Ana Carolina. A defesa da concorrência e a defesa do consumidor no setor de planos e seguros de saúde no Brasil. In: Aspectos jurídicos e econômicos das coope- 
rativas de saúde. Guilherme Krueger e Lucila Carvalho Medeiros Rocha (coord.). Belo Horizonte: Del Rey, 2012, pp.141-165.

Gilberto, André Marques. O processo antitruste sancionador. Dissertação de mestrado. USP. São Paulo: 2008, pp. 245-246.

Grau, Eros Roberto. A ordem econômica na constituição de 1988: interpretação e crítica. 17. ed. rev. atual. São Paulo: Malheiros Editores, 2015, pp. 45-47.

HART, Oliver; Moore, John. Cooperatives vs outside ownership. Havard University, 1998, pp. 4-5. Disponível em: < https://scholar.harvard.edu/hart/ publications/cooperatives-vs-outside-ownership>. Acesso em: 09 abr. 2016.

International Co-Operative Aliance (ICA), World Co-operative monitor: exploring the co-operative economy. Report 2016. ICA, pp. 8-47. Disponível em: $<$ https://ica.coop/en/media/library/the-world-co-operative-monitor-2016edition>. Acesso em: 18 dez. 2017.

KRUEGER, Guilherme. Os sonhos interrompidos e os rostos humanos nos serviços de saúde: a cooperação como um ato de preferência dos médicos e dos cirurgiões-dentistas». In: KRUEGER, Guilherme; RoCHA, Lucila Carvalho Medeiros da (coord.). Aspectos jurídicos e econômicos das cooperativas de saúde. Belo Horizonte: Del Rey, 2012, p. 32.

LAMMING, Goodwin Norman. Eficiência em administração de cooperativas. In: A problemática do cooperativismo no desenvolvimento econômico. São Paulo: Fundação Friedrich Naumann, 1973, pp. 281-314.

Maier-Rigaud, Frank P.; Hellstrom, Per; Bulst, Friedrich Wenzel. Remedies in European Antitrust Law (May 3, 2011). Antitrust Law Journal, Vol. 76, pp. 43-63, 2009, p. 57.

MEINEN, Ênio. As sociedades cooperativas na Constituição Federal. In: DOMINGUES, Jane Aparecida Stefanes (org.). Aspectos jurídicos do cooperativismo. Série Cooperativas I. Porto Alegre: Editora Sagra Luzzatto, 2002, pp. 11-47.

Nascimento, Carlos Valder do. Teoria geral dos atos cooperativos. São Paulo: Malheiros, 2007, pp. 52-92.

OliveIRA, Gesner; RODAS, João Grandino. Direito e economia da concorrência. 2. ed. rev. e atual. São Paulo: Revista dos Tribunais, 2013, p. 52.

OrganizaÇÃo das CoOperativas Brasileiras (OCB). Relatório de GEStão OCB 2016. SOMOS COOPERATIVISMO. Brasília, 2016. Disponível em: <http://www.somoscooperativismo.coop.br/transparencia-ocb>. Acesso em: 18 dez. 2017.

- Anuário do Cooperativismo Brasileiro 2019. Brasília: Sistema OCB, 2019, p. 45. Disponível em: < https://www.ocb.org.br/publicacao/53/anuario-docooperativismo-brasileiro-2019>. Acesso em 02 set. 2020.

PInHo, Diva Benevides. Economia e cooperativismo. São Paulo: Saraiva, 1977, pp. 13-75.

SINGER, Paul. Economia solidária versus economia capitalista. Revista Sociedade e Estado. Instituto de Ciências Sociais da Universidade de Brasília. vol. 16. n.1-2. Brasília: jun./dez., 2001, pp. 109-110. Scielo. Disponível em:<http:// dx.doi.org/10.1590/S0102-69922001000100005>. Acesso em: 02 jul. 2016. 


\section{Derechos de autor}

http://dec.revistas.deusto.es/

La revista Deusto Estudios Cooperativos es una revista de acceso abierto lo que significa que es de libre acceso en su integridad inmediatamente después de la publicación de cada número. Se permite su lectura, la búsqueda, descarga, distribución y reutilización legal en cualquier tipo de soporte sólo para fines no comerciales y según lo previsto por la ley; sin la previa autorización de la Editorial (Universidad de Deusto) o el autor, siempre que la obra original sea debidamente citada (número, año, páginas y DOI si procede) y cualquier cambio en el original esté claramente indicado.

\section{Copyright}

The Deusto Journal of Cooperative Studies is an Open Access journal which means that it is free for full and immediate access, reading, search, download, distribution, and lawful reuse in any medium only for non-commercial purposes, without prior permission from the Publisher or the author; provided the original work is properly cited and any changes to the original are clearly indicated. 